\title{
THE DEVELOPMENT OF LEGAL POLITICS IN MICRO BUSINESS POLICY OF JOMBANG REGENCY GOVERNMENT
}

\author{
Moh. Faizin ${ }^{1 *}$, Surya Anoraga ${ }^{2}$ \\ ${ }^{1 *}$ Faculty of Law, Muhammadiyah University of Sidoarjo, Indonesia, \\ ${ }^{2}$ Magister Ilmu Hukum, University of Muhammadiyah Malang, Indonesia, \\ faizin@umsida.ac.id* (corresponding).
}

\begin{abstract}
This paper aim to talk about legal politics, then talking about legal products produced by the authorities, whether they hear the aspirations of the people in the process of their formation or are more concerned with the interests or goals of the rulers themselves. Political influence in the formation of law determines the values contained in the law in its application in society to achieve the goal of the law itself, namely justice. The purpose of the research that the author examines is to describe the formation of the Jombang Regency Regional Regulation Number 9 of 2017 concerning Responsive or Repressive Micro Government. The research method used is a normative research method with a statute approach. Based on the process of its formation, the Jombang Regency Regulation Number 9 of 2017 already contains the principles for the formation of laws and regulations, and is in accordance with the needs of the Jombang community.
\end{abstract}

Keywords: Legal Politics; Policy Administration; Micro Business

\section{INTRODUCTION}

Speaking of the politics of law then talking about the legal products produced by the ruler whether hearing the aspirations of the people in the process of its formation or whether more concerned with the interests or goals of the ruler himself (Hajiji, 2013). This is an inseparable part when we discuss the politics of law. Political influence in the formation of law determines the values contained in the law, based on the values that live in society in achieving the legal goal itself, namely justice (Asmuni, 2017).

In the establishment of laws and regulations, both the formation of regulations in the central government and in local government, it will not be separated from legal politics. Referring to padmo Wahyono's opinion, it defines that the basic policy that determines the direction, basis, and content of the law that will be formed is the definition of legal politics, it can substantively be interpreted that all policies or legal policies about the process / step in the enactment of the law in order to achieve the ideals of the nation and the goals of the state (Soekanto, 1988). Any process of legal formation in producing a legal product will greatly affect the characteristics of the legal product, whether the resulting law provides justice for the small people (responsive), or vice versa, the condition of the political interests of the ruler, does not heed the needs and interests of the people (repressive), similarly, the character of the law in Indonesia will not be separated from the name of legal politics (Riawanti, 2014). 
The State of Indonesia is a unitary state in the form of republik (article 1 paragraph 1 of the Constitution'45) and the highest governmental power is in the hands of the president (Article 4 paragraph 1). Based on the mandate of the 1945 Constitution, the Indonesian system of government is centralized in the hands of the central government (centralistic). The geographical condition of Indonesia consisting of 34 provinces and thousands of islands (Nawangsari et al., 2021), is very difficult if implementing a fully centralized system of government, especially in the making of rules / policies will not be effective for each region with different characters and problems. Responding to these conditions, as one of the basic considerations of the central government in giving authority to the local government (related to the affairs of the Concurrent Government) to take care of the affairs of its own local government or commonly known as regional autonomy. Local governments can exercise the widest autonomy, except for government affairs which by law are determined as the affairs of the central government, thus in this case giving rise to a relationship of authority between the central government and the government in the region.

The delegation of authority from the central government can be done by decentralization, decentralization or assistance duties. Related to regional autonomy itself has been regulated in Law No. 23 of 2014 on Local Government which was previously regulated in law No.32 of 2004 on local government. Based on Law No. 23 of 2004 on Local Government, the local government here is the provincial government and the district / city government has the right to organize their local government affairs in accordance with the local wisdom of each region. Regional authorities have regional autonomy to manage their government affairs, meaning that the local government has the authority to make policies about its local government or better known as local regulations (Fitriana, 2015).

As explained earlier above that the local government has the authority to take care of local government affairs in accordance with local cultural wisdom, as well as Jombang regency can make policies in accordance with the wisdom of local culture which is related to micro-businesses Jombang district government has made Jombang Regency Regulation On Micro Business No. 9 of 2017 on Micro Business.

Jombang Regency is one of the districts located in the province of East Java, known as the city of Santri making jombang as one of the religious, culinary, educational tourist destinations in east Java (Rahmawati \& Fauzi, 2021). With these characteristics become one of the sources of income for the local government and the people of Jombang. To support a conducive trade climate, the jombang regency government issued Jombang Regency Regulation No. 9 of 2017 on Micro-Business Governance. In the establishment of Jombang Regency Regulation on MicroBusiness Governance No. 9 of 2017 on Micro Business, the author will try to preach related to the regulation is responsive or repressive.

Based on the search data that the author conducted on the journal search site lens.org by including the word political development of micro business policy law, the author found there were 501 articles, then the author tried to filter the article in the last 5 years found data as many as 306 articles, then the author tried to do a special filter article I Ndonesia, the author found 56 articles, then the author conducted a special filtration of legal journals obtained data as many as 8 legal journals. But in the 8 articles that have been written, no one discusses the same legal issues that the author raised. The author tried to search in google schoolar related to previous 
research relevant to the research that the author raised, the author only found 1 (one) research relevant to the research that the author raised that discussed the politics of the protection of MSMEs in the ASEAN Economic Community/AEC (Sitorus, 2018) where the focus of the discussion is different from that of the author of the study. The establishment of Jombang Regency Regulation No. 9 of 2017 concerning Micro-Business Governance is Responsive or Repressive.

The purpose of the research that the author examined was to describe the development of legal politics in the establishment of Jombang Regency Regulation No. 9 of 2017 on MicroBusiness Governance is Responsive or Repressive. The author hopes that this research can contribute to the contribution of thinking in realizing better legal politics.

\section{METHODOLOGY}

The research method that the author uses is a normativ research method with a statue approach (Hermanto et al., 2021) (Esfandiari \& Putra, 2021). The steps taken by the author are, first the author collects existing legal materials both law, journals and books (Umami et al., 2021) (Al-Fatih, 2020). This research is also called doctrinal legal research or theoretical legal research (Sulihin, 2021). The author also looks for previous research that relefan with the research that the author researched in the last 5 years. After the legal material is obtained, the author conducts an analysis based on the character of the resposive law and repressive law according to the nonet, then obtained results and conclusions.

\section{RESULTS AND DISCUSSION}

In Jombang Regency Regulation No. 9 of 2017 on Micro-Business Governance, contains related efforts of the jombang district government in synergy with micro business actors so that micro businesses can grow and compete,

1. Micro-Business Construction

a. Coordinating Institutional Development

b. Increase in HUMAN RESOURCES

2. Facilitation of Micro Business Development

a. Capital loans

b. Production Development

c. Increased Productivity

3. Data collection for legal protection

4. Penalty

In the minutes of the regulation explained that the establishment of Jombang Regency Regulation No. 9 of 2017 on Micro-Business Governance on micro-business governance aims to build the community economy and employment for poverty reduction, as well as the empowerment of micro-business actors to provide a healthy business climate for the welfare of the community. Based on data obtained from the website of the Jombang district government office, the data is improved related to the number of MSMEs in Jombang regency as it is equivalent.

TABLE 1. POTENTIAL OF SMALL AND MEDIUM-SIZED INDUSTRIAL CENTERS IN 2017

Business Field $\begin{gathered}\text { Number of } \\ \text { Centers }\end{gathered} \quad \begin{gathered}\text { Business } \\ \text { Unit }\end{gathered} \quad$ Workforce




\begin{tabular}{|c|c|c|c|}
\hline Kitchen appliances (stove) & 3 & 30 & 130 \\
\hline Corn ampok & 1 & 7 & 21 \\
\hline Bamboo Webbing & 19 & 437 & 788 \\
\hline Pandan Woven & 38 & 1823 & 3686 \\
\hline Red Brick & 21 & 578 & 1171 \\
\hline Batik & 2 & 20 & 50 \\
\hline Brass Statue & 1 & 15 & 95 \\
\hline Aluminum Recycling & 3 & 46 & 358 \\
\hline Emping mlinjo & 1 & 32 & 46 \\
\hline Tile & 5 & 194 & 1058 \\
\hline Clay pottery & 3 & 103 & 705 \\
\hline Gibs & 3 & 23 & 110 \\
\hline Jampel (parsing cloth doormat) & 1 & 12 & 36 \\
\hline $\begin{array}{l}\text { Jamu sling / Instant herbal } \\
\text { medicine }\end{array}$ & 4 & 38 & 70 \\
\hline Fried Beans & 1 & 15 & 35 \\
\hline Glass Calligraphy & 2 & 14 & 44 \\
\hline Wood Calligraphy & 1 & 2 & 8 \\
\hline Confection / Embroidery & 3 & 58 & 215 \\
\hline Crackers & 9 & 179 & 594 \\
\hline Wet cake-s & 2 & 29 & 88 \\
\hline Glutinous lepet & 1 & 14 & 21 \\
\hline Lontong Rice & 1 & 12 & 17 \\
\hline Bead-2 of glass & 3 & 90 & 455 \\
\hline Furniture & 5 & 108 & 351 \\
\hline Burci (Party dress) & 1 & 25 & 100 \\
\hline Iron Pande & 7 & 155 & 580 \\
\hline Candy Tape & 1 & 6 & 24 \\
\hline Fried Bread & 1 & 16 & 26 \\
\hline Shoe & 2 & 11 & 110 \\
\hline Know & 3 & 47 & 152 \\
\hline Glutinous Tape & 1 & 13 & 35 \\
\hline Bag \& Wallet & 2 & 58 & 286 \\
\hline Plastic bags & 1 & 15 & 55 \\
\hline Tasbih banana seeds & 1 & 17 & 34 \\
\hline Tempeh & 6 & 175 & 354 \\
\hline Gadung & 1 & 15 & 20 \\
\hline Total & 160 & 4432 & 11928 \\
\hline
\end{tabular}

Data Source: Cooperative and MSME Office

Based on table 1. The above can be seen that the potential of micro-businesses in Jombang regency is very large, namely as many as 4,432 business units. and based on the explanation of the content contents of the regulation above, it can be said that Jombang Regency Regulation No. 
9 of 2017 on Micro-Business Governance is a responsive legal product and for analysis related to it will be discussed in the discussion below.

\section{Analysis of Jombang Regency Draft No. 9 of 2017}

If we look at the contents in the above regulation whether included in a responsive or repressive regulation, then we need to know about the types of laws, characteristics of the legal type, only then we can find out the characteristics of the regulation can be said to be responsive or repressive.

The type of legal product, in fact the type of legal product is divided into 3, namely, 1) repressive laws, 2) laws that are autonomous, 3) laws that are responsive (Sodiq, 2016). If we conclude that the fundamental differences of the three types of laws according to Nonet are related to the coercion of the three types of laws where domonan coercion in repressive law, coercion is in autonomous law, and low coercion in responsive law. In our discussion this time, the author will only try to discuss related to Repressive Law and responsive law (Andrianto, 2020).

The first analysis conducted by the author is based on the urgency / needs of the issue of Jombang Regency Regulation No. 9 of 2017 on micro-business governance. Based on historical analysis conducted by the author of the jombang regional regulations that specifically discuss related to micro-businesses or the like, there is no special regulation that regulates the arrangement of micro-businesses in Jombang considering that each region has regional autonomy, seeing the legal facts that occur in Jombang that many micro-businesses in Jombang based on table 1 above, Considering Jombang as many religious tourism cities so it is necessary to make special rules as a legal umbrella that regulates and related MSMEs as a form of support from the jombang government to the umkm industry in Jombang. Related to the previous regulation of Jombang Regency Regulation No. 9 of 2017 on Micro businesses, micro-business actors only under the law of Law No. 20 of 2008 concerning MSMEs and Government Regulation No. 17 of 2013 which in practice there are still many weaknesses.

The second author analysis is based on the principles of the establishment of laws and regulations which are regulated in Law number 12 of 2011 on the establishment of laws and regulations (Law 12/11) in article 5 explaining the general principles of good governance that contain about a. clarity of purpose; $b$. appropriate institutions or forming officials; c. conformity between type, hierarchy, and matter of charge; d. can be implemented; e. versatility and usefulness; f. clarity of formulation; and g. openness. In one of the points explained related to the principle of openness which in the explanation of Law 12/11 mentioned that there is involvement and active role of the community in the preparation of a law. In Law number 12 of 2011 mentioned that in the establishment of legislation, it must be based on academic manuscripts made by third parties. Academic manuscripts are formal legal in reference to the establishment of laws and regulations that contain aspects of philosophical, judicial and sociological land. In the formation of this academic text, the community can convey its aspirations so that the concerns made are responsive.

Seeing the description above, an inevitability for the author in analyzing Jombang Regulation No.9 of 2017 on Micro-Business Governance without heeding the Academic Manuscript of raperda preparation. In the academic manuscript Raperda Jombang on MicroBusiness the author will only take points from the academic manuscript which according to the author as the point of the academic manuscript. In the akdemik text explained that there is no 
district / city regulation as a legal basis for micro-business activities. Then the importance of the role of the government in various levels in tackling unemployment. The last point is that this academic manuscript has contained rules, values that live in society.

Based on the characteristics of legal products according to Mahfud MD where responsive law reflects a sense of justice and meets the expectations of the community, and in its manufacture accommodates the aspirations of the community (participatory), which is an affirmation related to the role of society is very important to produce responsive legal products (Hadi, 2015). In saving the author related to Jombang Regulation No.9 of 2017 on MicroBusiness in its academic manuscript has involved the role of the community in its preparation so that jombang regulation No.9 of 2017 on Micro-Business Governance and also see article 5 of Law 12/11 can be said as a responsive legal product.

\section{CONCLUSION}

Jombang Regency Regulation No. 9 of 2017 on Micro-Business Governance is Responsive which can be seen from the characteristics of the formation of the regulation based on the interests of the community. Jombang Regency Regulation No. 9 of 2017 on Micro-Business Governance contains the provisions contained in Law number 12 of 2011 on the establishment of laws and regulations, must be based on academic manuscripts in which academic manuscripts contain philosophical, sociological and juridical rules, and accommodate the aspirations of citizens, so that they are responsive. The role of the community determines the regulation is repressive or responsive.

\section{REFERENCES}

Al-Fatih, S. (2020). Penerapan Threshold dalam Pemilu Menurut Perspektif Gustav Radbruch dan Hans Kelsen. Audito Comparative Law Journal (ACLJ), 1(2), 78-84. https://doi.org/10.22219/audito.v1i2.13973

Andrianto, F. (2020). Kepastian Hukum dalam Politik Hukum di Indonesia. Administrative Law and Governance Journal, 3(1), 114-123. https://doi.org/10.14710/alj.v3i1.114-123

Asmuni. (2017). Political Influence in The System of Regional Election in Indonesia. Unram Law Review (ULREV), 1(1), 79-99. https://doi.org/10.29303/ulrev.v1i1.7

Esfandiari, F., \& Putra, A. M. A. (2021). Implementation of Consistent Pilkada in Malang District From Precautionary Principles. Audito Comparative Law Journal (ACLJ), 2(1), 1118. https://doi.org/10.22219/aclj.v2i1.15157

Fitriana, M. K. (2015). Laws and Regulations in Indonesia as The Means of Realizing The Country's Goal. Journal Legislasi Indonesia, 12(2), 1-27. https://doi.org/10.54629/jli.v12i2.403

Hadi, S. (2015). Pengaruh Konfigurasi Politik Pemerintah Terhadap Produk Hukum. ADDIN: Media Dialektika Ilmu Islam, 9(2), 383-400. http://dx.doi.org/10.21043/addin.v9i2.620

Hajiji, M. (2013). Legal and Political Relations in the Indonesian Legal System. Journal of Rechts Vinding: Media of National Legal Development, 2(3), 361-373. 
https://doi.org/10.33331/rechtsvinding.v2i3.65

Hermanto, L. O., Bachri, S., \& Siregar, W. A. (2021). Penegakan Hukum Tindak Pidana Pemilu Terhadap Penggunaan Hak Pilih Orang Lain. Audito Comparative Law Journal (ACLJ), 2(3), 143-154. https://doi.org/10.22219/aclj.v2i3.17329

Nawangsari, E. R., Fridayanti, E. Y., Almira, A. I., \& Nugrohowati, R. H. (2021). Peran Pemerintah Daerah dalam Memberdayakan Usaha Mikro Kecil dan Menengah di Kabupaten Tuban. Muqqodimah: Jurnal Ilmu Sosial, Politik Dan Humaniora, 5(2), 345352. https://doi.org/10.31604/jim.v5i2.2021.345-352

Rahmawati, W. D., \& Fauzi, A. M. (2021). Perebutan Ruang Publik Pedagang Kaki Lima pada Masa Pandemi di Alun-Alun Jombang. JIDS: Jurnal Ilmiah Dinamika Sosial, 5(1), 17-32. https://doi.org/10.38043/jids.v5i1.2971

Riawanti, W. (2014). Kajian Ekonomi Politik Bantuan Modal Masyarakat Miskin Studi Kasus Kebijakan Bantuan Dana Pelaku Usaha Mikro (UKM) Di Kabupaten Bantul. OPTIMUM: Jurnal Ekonomi Dan Pembangunan, 4(1), 1-12. http://dx.doi.org/10.12928/optimum.v4i1.7793

Sitorus, A. P. (2018). Political Law on the Protection of Small and Medium Enterprises (Msmes) in the Asean Economic Community. Doctrinal: Journal of Law, 1(2), 125-144. https://doi.org/10.31289/doktrina.v1i2.1920

Sodiq, N. (2016). Membangun Politik Hukum Indonesia Bercorak Responsif Perspektif Ius Constituendum. Jurnal Magister Hukum Udayana, 5(2), 233-351. https://doi.org/10.24843/JMHU.2016.v05.i02.p02

Soekanto, S. (1988). Ilmu Politik dan Hukum. Jurnal Hukum Dan Pembangunan, 18(3), 230237. https://doi.org/10.21143/jhp.vol18.no3.1258

Sulihin, L. O. M. (2021). Perluasan Unsur Obyektif Tindak Pidana Pemilihan dalam Pasal 188 jo Pasal 71 Undang-Undang Pemilihan Gubernur, Bupatim dan Walikota. Indonesian Law Reform Journal, 1(2), 288-302. https://doi.org/10.22219/ilrej.v1i2.17419

Umami, R., Haruni, C. W., \& Esfandiari, F. (2021). Tingkat Partisipasi Politik Masyarakat dalam Pilkades Serentak Tahun 2019. Indonesia Law Reform Journal (ILREJ), 1(1), 143-152. https://doi.org/10.22219/ilrej.v1i1.16123 